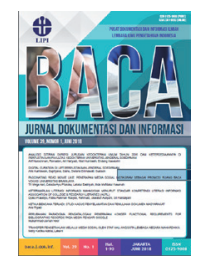

\title{
Keberhasilan kompetensi literasi digital sebagai tolok ukur soft skills mahasiswa lulusan kearsipan
}

\author{
Dewi Maharani ${ }^{1 *}$; Wijayanti². \\ ${ }^{1}$ Universitas Terbuka \\ ${ }^{2}$ Universitas Persada Indonesia \\ *Korespondensi: dewi.rachmaningsih@ecampus.ut.ac.id
}

Diajukan: 29-09-2020; Direview: 31-01-2021; Diterima: 21-04-2021; Direvisi: tgl-bln-thn

\begin{abstract}
This article was written to deliver the idea of the need for digital literacy competencies for archival graduate students in an era of disruption to meet the needs of users and professional development so that in the end the success of digital literacy becomes a new benchmark for soft skills competencies for archiving program graduates. This research is a descriptive qualitative study using the FGD method for collecting data from informants, namely users and graduates of the archiving program itself. The results show that graduates of archives have not been able to meet the needs of soft skill competencies according to user demands, especially regarding the use of digital technology in supporting the implementation of tasks and jobs. It is suggested that college can facilitate the efforts to increase digital literacy competence through learning methods, in addition to students also trying to improve their experience in the use of digital technology.
\end{abstract}

\begin{abstract}
ABSTRAK
Artikel ini ditulis untuk menyampaikan ide perlunya kompetensi literasi digital bagi mahasiswa lulusan kearsipan di era disrupsi guna memenuhi kebutuhan dari pengguna dan pengembangan profesionalisme, sehingga pada akhirnya keberhasilan literasi digital menjadi tolok ukur kompetensi soft skills bagi lulusan program studi kearsipan. Penelitian bersifat kualitatif deskriptif dengan menggunakan metode FGD virtual guna mengumpulkan data dari para informan. Informan terdiri dari pengguna dan lulusan program kearsipan. Hasil penelitian menunjukkan bahwa lulusan kearsipan belum dapat memenuhi kebutuhan kompetensi soft skills sesuai permintaan pengguna, terutama terkait pemanfaatan teknologi digital dalam mendukung pelaksanaan tugas dan pekerjaan. Disarankan agar program studi dapat memfasilitasi upaya peningkatan kompetensi literasi digital melalui metode pembelajaran, disamping mahasiswa juga berupaya meningkatkan pengalamannya dalam pemanfaatan teknologi digital.
\end{abstract}

Keywords: Success; Digital literacy competencies; Benchmark; Soft skills.

\section{PENDAHULUAN}

Tuntutan dunia kerja dan profesionalisme bagi lulusan program studi kearsipan mensyaratkan kemampuan komunikasi dan koordinasi yang didukung penguasaan teknologi digital dalam pengelolaan dan pemanfaatan dokumen kearsipan. Sebagai program vokasi, capaian program studi kearsipan adalah lulusan yang mumpuni, selain pencapaian indeks prestasi keilmuan juga memiliki berbagai kemampuan pendukung yang akan membantu mereka sukses melaksanakan tugas dan pekerjaan.

Pemanfaatan media digital tidak saja membutuhkan kemampuan teknis mengakses teknologi tetapi juga memahami konten, memformulasi pesan, serta mengembangkan fungsi aktif dan interaktif. Konsep dan dimensi literasi digital sepenuhnya bermuatan teknologi, psikologis dan sosial, sehingga dapat dipahami bahwa literasi digital adalah bentuk keterampilan yang kompleks dan menyangkut keterampilan baru yang harus dimiliki dalam lingkungan digital yang sedang berkembang pesat. 
Istilah literasi digital pertama kali dikemukakan oleh Paul Gilster sesuai dengan judul buku "Digital Literacy" (Riel, et al., 2012) dan didefinisikan sebagai kemampuan menggunakan teknologi dan informasi dari piranti digital secara efektif dan efisien dalam berbagai konteks baik akademik, karir, maupun kehidupan sehari-hari, ditambahkan oleh Eshet (2004) bahkan juga merupakan bentuk cara berpikir tertentu.

Pada generasi milenial penggunaan teknologi informasi bukanlah hal baru, mereka cukup akrab dengan piranti digital ini. Permasalahannya adalah mampukah mereka memanfaatkan teknologi tersebut sebagai sarana pendukung baik pada proses pembelajaran maupun pekerjaan sesuai bidang akademis. Identifikasi perlu segera dilakukan, menjadi penting untuk mengetahui apakah literasi digital memang sudah seharusnya menjadi bagian dari soft skills. Penelitian ini bertujuan untuk mengidentifikasi literasi digital yang menjadi kebutuhan skill baru di dunia kerja sebagai pendukung hard skills, utamanya untuk lulusan program studi kearsipan.

Tujuan penelitian ini adalah untuk menjelaskan pengembangan kemampuan literasi digital pada mahasiswa vokasi yang bisa dimulai untuk diupayakan dan difasilitasi untuk kompetensi lulusan program kearsipan dalam rangka memenuhi tuntutan soft skills dunia kerja; keberhasilan kemampuan literasi digital dapat menjadi tolak ukur soft skills lulusan program studi Kearsipan; penyesuaian metode pengajaran dalam upaya pencapaian kemampuan literasi digital pada lulusan program kearsipan. Penelitian ini lebih fokus pada identifikasi berbagai kemampuan yang diperlukan seorang lulusan program studi Kearsipan dalam mengaplikasikan ilmunya di dunia kerja.

\section{TINJAUAN PUSTAKA}

Jordana dan Suwarto (2017), dalam penelitiannya 'Pemetaan Program Literasi Digital Di Universitas Negeri Yogyakarta'. Peneliti menggunakan metode deskriptif-kualitatif mencoba untuk memetakan gerakan literasi digital yang dilakukan di lingkup Universitas Negeri Yogyakarta (UNY). Hasil analisis menunjukkan bahwa dari sejumlah aktivitas literasi digital: satu kegiatan literasi merupakan aktivitas Protectionism, empat kegiatan literasi adalah aktivitas Active Audience, selanjutnya tujuh kegiatan literasi merupakan aktivitas Critical Analytical, sisanya merupakan aktivitas Creative Media, dan gabungan (mengadopsi gabungan Creative Media dan Media Fun atau gabungan Critical Analytical dan Media Fun).

Andi Asari dkk. (2019) melakukan penelitian dengan judul 'Kompetensi Literasi Digital Bagi Guru Dan Pelajar Di Lingkungan Sekolah Kabupaten Malang'. Kesimpulan dari penelitian tersebut adalah solusi praktis pembelajaran literasi digital bermanfaat dalam membangun kompetensi literasi digital bagi guru dan pelajar, sebagai bagian dari upaya membentuk SDM yang berkarakter dalam memajukan pendidikan di Indonesia. Metode yang digunakan adalah pelatihan secara kontinyu dalam menyelesaikan berbagai permasalahan melalui pemanfaatan teknologi digital, dengan demikian keahlian dasar menjadi aspek yang harus dimiliki oleh guru dan pelajar sementara keahlian tingkat lanjut diperlukan pada proses memaknai setiap informasi yang didapatkan dari media digital. Berikut sepuluh tahap kompetensi literasi digital baik pada tingkat dasar ataupun lanjutan: mengakses sistem, menyeleksi informasi, memahami informasi, menganalisis data, memverifikasi informasi, mengolah data/dokumen, mengevaluasi, mendistribusikan, memproduksi pesan, serta berpartisipasi dan berkolaborasi digital.

Literasi digital menurut Bawden (2001) berakar pada literasi komputer dan literasi informasi. Literasi komputer mengacu pada penggunaan alat baik untuk komunikasi, pemecahan masalah, pengorganisasian bahkan penelitian. Literasi komputer berkembang terlebih dahulu, sekitar tahun 1980an. 10 tahun kemudian diikuti dengan perkembangan literasi informasi. Literasi informasi dipelopori oleh para pustakawan dalam upaya merumuskan pengguna baru perpustakaan. Society 
of College, National, and University Libraries (SCONUL) di UK (Allan Martin, dalam Lankshear, $\mathrm{C}$ and Knobel, M (ed). 2008; 151-176), yang dimaksud dengan literasi informasi disini merupakan keterampilan mental dalam memahami dan memproduksi informasi baru, sementara literasi komputer adalah keterampilan fisik atau hard kompetensi terkait kemampuan menggunakan peralatan untuk mengakses serta mengetahui sumber informasi.

Bawden (2001) menjelaskan aspek-aspek literasi digital menyangkut hal berikut ini:

a. Perakitan pengetahuan merupakan kemampuan memanfaatkan sumber terpercaya untuk membangun informasi baru.

b. Menyajikan informasi merupakan kemampuan berpikir kritis untuk memahami informasi dengan kewaspadaan terhadap validitas dan kelengkapan data yang bersumber dari internet.

c. Kemampuan non sequential, yaitu mampu membaca dan memahami materi informasi yang tidak berurutan dan dinamis.

d. Kesadaran bermedia, mengetahui dan memahami peran penting berbagai bentuk media, baik konvensional maupun media berjaringan (internet) dan hubungan diantara keduanya.

e. Kesadaran pemanfaatan sumber rujukan dan akses jaringan orang yang dapat digunakan sebagai sumber data dan bantuan.

f. Kemampuan memfilter informasi, menyaring dan memanfaatkan berbagai informasi yang masuk.

g. Kenyamanan dalam memiliki akses dan memanfaatkan untuk mengkomunikasikan dan memublikasikan informasi.

Selanjutnya Bawden menegaskan bahwa terkait digital literasi keterampilan teknis untuk mengakses, merangkai, memahami dan mendistribusikan informasi sangatlah penting.

Konsep dari Buckingham (2007) menjelaskan bahwa literasi digital menyangkut empat komponen penting tentang; Representasi, Bahasa, Produksi dan Khalayak. Memanfaatkan media digital untuk merepresentasikan dunia adalah merefleksikan dunia itu sendiri, dan berbagai hasil interpretasi dan seleksi atas kenyataan. Untuk itu individu dituntut mampu berbahasa dengan memahami aneka jenis kode serta konvensi dalam berbagai genre konten, mampu memahami berbagai gaya retorika dan berbagai fungsi bahasa apakah itu sebagai persuasi, eufimisme atau hiperbola. Pada komponen produksi, literasi digital adalah kemampuan memahami objek dan subjek komunikasi, motif komunikasi serta kepentingan khalayak terkait konten dan keamanan, karena pada komponen khalayak literasi menuntut pemahaman tentang bagaimana media menempatkan khalayak dan menjadikannya target, merespon khalayak, memanfaatkan informasi dari khalayak dengan memperhatikan masalah privasi dan keamanan pengguna.

Capaian kompetensi literasi digital pada setiap individu tidaklah sama dan dapat dimulai dari interaksi jenjang yang berbeda, namun tetap harus memiliki kompetensi dasar seperti yang termaktub pada level 1 (lihat Gambar 1.) Pada literasi digital tingkat satu, penting untuk setiap individu mampu mengembangkan konsep, pendekatan, serta sikap dan tindakan ketika memanfaatkan media digital. Pada tingkat dua, adalah pengembangan kemampuan dalam menerapkan aplikasi untuk tujuan produktif/profesional seperti pemanfaatan untuk bisnis, pengajaran, kampanye sosial, dan sebagainya. Pada di tingkat teratas, level transformasi digital, diharapkan individu telah mampu berinovasi dan secara luas menggunakan media digital seperti produktivitas pesan, penciptaan karakter di dunia maya, berbagi dan berkolaborasi, serta pemanfaatan multimedia. 


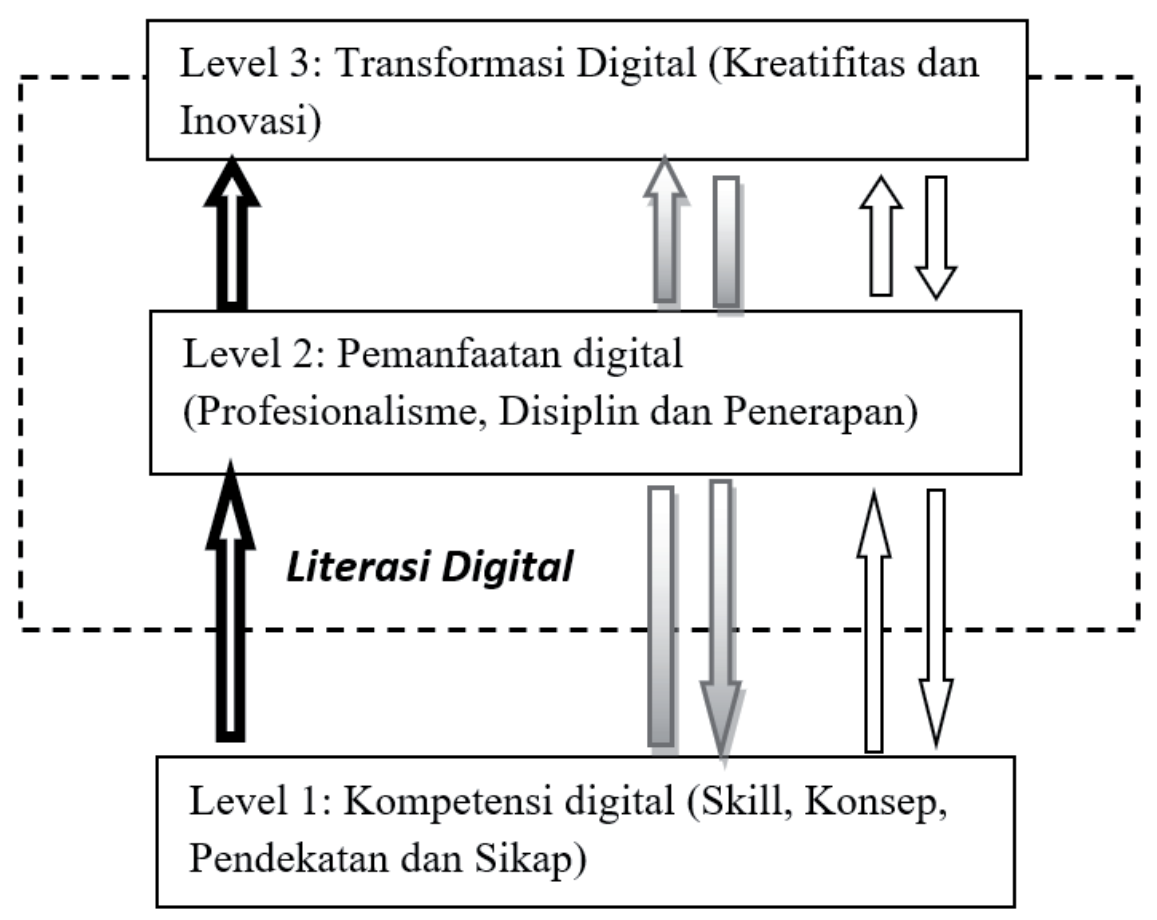

Gambar 1. Tingkat Literasi Digital

Sumber: Lankshear dan Knobel 2008, 167

\section{METODE}

Penelitian ini bersifat kualitatif deskriptif menggunakan metode Focus Group Discussion (FGD) untuk menghimpun data. FGD dilaksanakan secara virtual melalui link room: https://sl.ut.ac.id/ ArsiparisSoftskill. pada bulan Juli 2020, dengan 6 peserta, terdiri dari 4 peserta sebagai informan, dua peserta lainnya bertindak sebagai fasilitator dan notulen, sementara peneliti hadir sebagai pengamat. Informan adalah para pengguna lulusan program studi Kearsipan. Para informan diminta untuk menjawab pertanyaan dan memberi masukan pada saat forum diskusi. Sebelumnya mereka juga diminta untuk mengisi e-form guna menjawab pertanyaan-pertanyaan serupa terkait masalah kompetensi, soft skills dan disrupsi digital. Analisis permasalahan dilakukan dengan menarik benang merah atas jawaban dan berbagai masukan dari informan.

\section{HASIL DAN PEMBAHASAN}

\section{Hasil Penelitian}

Poin penting yang bisa diambil dari diskusi yang dilaksanakan pada tanggal 4 Juli 2020, adalah bahwa sistem perkuliahan belum dapat mengakomodir sepenuhnya untuk pengembangan soft skills lulusan vokasi program studi Kearsipan, utamanya terkait pemanfaatan teknologi digital. Aktivitas kehidupan generasi milenial yang akrab dengan penggunaan teknologi digital sehari-harinya ternyata tidak menjamin penguasaan atas teknologi tersebut adalah fakta sosial yang tidak bisa kita tolak. Ketika lulusan program studi Kearsipan belum dapat sepenuhnya memanfaatkan teknologi digital untuk mendukung tugas dan pekerjaan mereka maka dianggap belum punya skill atau skillnya masih kurang. Penguasaan teknologi adalah sebuah proses learning by doing and learning by experience. Menurut ibu Triana Widyaningrum ketika menyampaikan pendapatnya pada forum diskusi tanggal 4 Juli 2020. Perguruan Tinggi harus dapat mencermati hal-hal berikut: 
Tabel 1. Hasil FGD

\begin{tabular}{|c|c|c|}
\hline No. & Permasalahan & Hasil Analisa \\
\hline 1 & Pemahaman disrupsi digital & $\begin{array}{l}\text { Sepakat, terjadinya perubahan besar dan mendasar pada masyarakat } \\
\text { karena adanya perkembangan teknologi dan telekomunikasi yang } \\
\text { pesat. }\end{array}$ \\
\hline 2 & Pemahaman soft skills & $\begin{array}{l}\text { Sepakat, kemampuan dalam berkomunikasi dan berinteraksi, } \\
\text { mampu bekerjasama, berkoordinasi, kepemimpinan serta sikap dan } \\
\text { perilaku. } \\
\text { Sepakat, soft skills di era disrupsi ditentukan oleh kemampuan se- } \\
\text { seorang dalam memanfaatkan teknologi digital untuk berkomunikasi } \\
\text { dan berinteraksi. } \\
\text { Pendapat, soft skills adalah bagaimana berkomunikasi dan berinter- } \\
\text { aksi, hal ini tidak diajarkan di bangku kuliah. } \\
\text { Pendapat, soft skills didapatkan melalui pengalaman. }\end{array}$ \\
\hline 3 & Pemahaman kompetensi & $\begin{array}{l}\text { Sepakat, kompetensi adalah capaian lulusan yang secara lengkap } \\
\text { terdiri dari hard skills dan soft skills. } \\
\text { Pendapat, kompetensi soft skills lebih dicari dan dibutuhkan saat } \\
\text { ini, utamanya terkait dengan pemanfaatan teknologi digital. }\end{array}$ \\
\hline 4 & $\begin{array}{l}\text { Fakta capaian soft skills } \\
\text { lulusan }\end{array}$ & $\begin{array}{l}\text { Sepakat, lulusan adalah generasi milenial yang sudah akrab dengan } \\
\text { teknologi digital. } \\
\text { Pendapat, masih perlu pelatihan dalam menerapkan teknologi digi- } \\
\text { tal untuk keperluan tugas dan pekerjaan. } \\
\text { Pendapat, sudah mahir bila diminta membuat video, powerpoint } \\
\text { presentasi maupun konten kekinian namun masih perlu belajar lagi } \\
\text { terkait penerapan teknologi digital dalam mengelola arsip dan doku- } \\
\text { men yang sebelumnya dipelajari secara konvensional di kampus. } \\
\text { Pendapat, teknologi konvensional masih perlu. }\end{array}$ \\
\hline 5 & $\begin{array}{l}\text { Kebutuhan pengguna lulu- } \\
\text { san program studi kearsipan } \\
\text { terkait soft skills }\end{array}$ & $\begin{array}{l}\text { Pendapat, penguasaan teknologi digital disamping tetap perlu me- } \\
\text { nguasai teknologi konvensional, karena bidang kearsipan akan tetap } \\
\text { memanfaatkan kedua jenis teknologi tersebut. } \\
\text { Pendapat, harus ada penguasaan teknologi digital. } \\
\text { Pendapat, penguasaan teknologi digital di semua lini. }\end{array}$ \\
\hline 6 & $\begin{array}{l}\text { Harapan akan kompetensi } \\
\text { soft skills yang dimiliki } \\
\text { lulusan kearsipan terkait pe- } \\
\text { manfaatan teknologi digital }\end{array}$ & $\begin{array}{l}\text { Pendapat, memiliki digital capability. } \\
\text { Pendapat, sinkronisasi teknologi dan teori, mampu mengelola arsip } \\
\text { modern, mampu menerapkan otomatisasi. } \\
\text { Pendapat, memiliki pengalaman baik secara organisatoris ma- } \\
\text { upun bermasyarakat dalam mengelola dan memanfaatkan teknologi } \\
\text { digital. }\end{array}$ \\
\hline
\end{tabular}

$7 \quad$ Saran pengguna

Pengembangan tools di perkuliahan untuk transformasi sumber daya manusia.

Pemanfaatan teknologi digital sudah mulai diterapkan di setiap perkuliahan melalui penugasan, proyek kerja dan pembuatan laporan ilmiah.

Update masalah dalam pengajaran dan pengetahuan kearsipan modern.

Meningkatkan pengalaman dengan berorganisasi dan terjun langsung ke masyarakat.

Tidak meninggalkan teknologi konvensional tetapi mengkombinasikannya dengan teknologi digital sesuai kebutuhan dalam mengelola arsip.

Pengembangan berpikir kritis dan kreatif. 


\section{Pembahasan}

Sebuah studi baru dari UNICEF mengenai keterampilan masa depan menunjukkan bahwa daya kreativitas, berpikir kreatif, dan keterampilan digital adalah tiga jenis kompetensi yang dianggap paling penting oleh remaja untuk masa depan mereka. Banyak remaja merasakan keterampilan tersebut tidak mereka dapatkan di sekolah. Hal ini sejalan dengan pendapat responden yang berasal dari sektor swasta, di mana mereka menyoroti kondisi kelangkaan keterampilan lunak yang signifikan di kalangan calon karyawan dan karyawan baru. (Lazuardhi Utama, 2020).

Table 2. Pengelompokan Kebutuhan Literasi Digital

\begin{tabular}{cllll}
\hline $\begin{array}{c}\text { No. } \\
\text { dan Sistem }\end{array}$ & $\begin{array}{l}\text { Aplikasi Alat } \\
\text { masi \& Data }\end{array}$ & $\begin{array}{l}\text { Kolaborasi, Ino- } \\
\text { vasi \& Kreasi }\end{array}$ & Perkembangan dan Budaya \\
\hline 1 & $\begin{array}{l}\text { Kemampuan } \\
\text { dasar komputer }\end{array}$ & $\begin{array}{l}\text { Representasi simbol } \\
\text { dan makna }\end{array}$ & $\begin{array}{l}\text { Berpikir kritis, ino- } \\
\text { vatif dan kreatif }\end{array}$ & $\begin{array}{l}\text { Kewargaan digital, menjadi bagian } \\
\text { berbagai platform }\end{array}$ \\
\hline 2 & $\begin{array}{l}\text { Penguasaan } \\
\text { hardware/tools }\end{array}$ & $\begin{array}{l}\text { Pencarian informasi } \\
\text { dan data }\end{array}$ & $\begin{array}{l}\text { Proses dan kelola } \\
\text { dokumentasi/ teks }\end{array}$ & Keragaman konten \\
\hline 3 & $\begin{array}{l}\text { Penguasaan } \\
\text { software dan } \\
\text { aplikasi }\end{array}$ & $\begin{array}{l}\text { Perakitan informasi } \\
\text { baru }\end{array}$ & $\begin{array}{l}\text { Pemanfaatan multi- } \\
\text { media }\end{array}$ & $\begin{array}{l}\text { Hak intelektual, keunikan dan origi- } \\
\text { nalitas }\end{array}$ \\
\hline 4 & $\begin{array}{l}\text { Pemanfaatan } \\
\text { jaringan }\end{array}$ & $\begin{array}{l}\text { Analisis penilaian } \\
\text { informasi dan sum- } \\
\text { bernya }\end{array}$ & Komunikasi efektif & $\begin{array}{l}\text { Penghargaan privasi, pemanfaatan dan } \\
\text { keamanan identitas diri }\end{array}$ \\
\hline 5 & $\begin{array}{l}\text { Pengembangan } \\
\text { design }\end{array}$ & $\begin{array}{l}\text { Pengambilan kesim- } \\
\text { pulan }\end{array}$ & $\begin{array}{l}\text { Penciptaan karakter } \\
\text { di dunia maya }\end{array}$ & $\begin{array}{l}\text { Agenda terprogram, kontinuitas \& } \\
\text { konsistensi }\end{array}$ \\
\hline 6 & Pengayaan & Penyimpanan data & Produktifitas pesan & Dampak teknologi \\
\hline 7 & & $\begin{array}{l}\text { Navigasi, pengarahan } \\
\text { dan penjelasan } \\
\text { informasi }\end{array}$ & $\begin{array}{l}\text { Berbagi dan kolabo- } \\
\text { rasi }\end{array}$ & \\
\hline
\end{tabular}

Sudah diakui bahwa keterampilan literasi digital merupakan salah satu faktor yang mendukung interaksi teknologi yang efektif dalam berbagai situasi pembelajaran yang berlangsung terus dalam aktivitas berbagai bidang (Kenton \& Blummer, 2010). Diketahui keseluruhan literasi digital berbagi banyak prinsip yang menentukan dengan bidang lain yang menggunakan pengubahan keaksaraan atau literasi untuk menentukan cara mengembangkan pengetahuan domain tertentu dan telah berkembang dalam pemahaman sistem pendidikan dengan berbagai pengaturan dalam standar internasional maupun standar nasional. Selanjutnya disepakati bahwa literasi digital yang dibangun di atas perluasan peran penelitian ilmu sosial di bidang literasi terdiri dari literasi visual, literasi komputer, dan literasi informasi. (Boyd \& Crawford, 2012: 662-679). Selanjutnya kemampuan literasi digital dievaluasi melalui tata bahasa individu, komposisi pesan, keterampilan mengetik dan kemampuan untuk menghasilkan tulisan/produksi pesan, gambar, audio, serta keterampilan desain menggunakan aplikasi teknologi. Semua mengacu pada kemampuan individu dalam memanfaatkan teknologi digital.

Digital capability adalah kombinasi antara soft kompetensi berupa kemampuan interaksi dengan hard kompetensi dalam bentuk berbagai kemampuan teknis, bisa didapatkan dengan memperkaya pengalaman baik melalui pengalaman organisasi ataupun terjun langsung ke masyarakat. Perguruan tinggi dapat memfasilitasinya dengan pengembangan tools sebagai pendukung pembelajaran/ perkuliahan dalam upaya transformasi human. (Wawan, Direktur SDM Kearsipan \& Sertifikasi ANRI; FGD 4 Juli 2020). 
Proses pengembangan dapat dilakukan dengan bekerja sama dan berkoordinasi dengan Lembaga Arsip Nasional Republik Indonesia (ANRI). ANRI telah mengeluarkan Peraturan Kepala Arsip Nasional Republik Indonesia Nomor 12 Tahun 2017 tentang Grand Design Pembinaan Sumber Daya Manusia Kearsipan. Harapannya sumber daya arsiparis akan dapat mengikuti perkembangan teknologi berbasis 4.0.

Para pengguna melalui penilaiannya terhadap para mahasiswa yang sedang magang di lembaganya masing-masing menjelaskan, bagaimana para mahasiswa benar-benar sangat minim kompetensi soft skills terutama dalam hal komunikasi dan ekspresi diri. Terkait literasi digital diakui bahwa para mahasiswa calon lulusan kearsipan sudah memiliki kemampuan IT yang cukup namun belum mampu memanfaatkannya dalam mendukung tugas dan pekerjaan. Bahkan kemampuan IT di bidang kearsipan masih dikategorikan kurang sehingga sedikit merepotkan para pembimbing magang. Pelaksanaan tugas-tugas ketika magang menjadi pengalaman baru bagi pemagang dalam upaya literasi digital. Mereka tidak mendapatkan skills tersebut ketika di bangku kuliah. Saran dari para informan berkembang agar terus dilakukan pembaharuan pengetahuan dan keterampilan (update knowledge) kearsipan baik secara materi maupun penugasan, proyek dan sistem pelaporan ilmiah.

Mengacu pada 7 aspek literasi digital dari Bawden dapat dirangkum bahwa hanya pada point ke 7 mahasiswa dapat dikatakan memenuhi aspek untuk dikatakan mampu, sementara pada 6 aspek lainnya mahasiswa hanya dapat memenuhi sebagian saja. Atas dasar tersebut maka dapat disimpulkan bahwa lulusan program studi kearsipan tidak dapat dikatakan telah mencapai keberhasilan literasi digital. Contohnya pada point 4 , mahasiswa baru mencoba menguasai teknologi digital bersamaan dengan itu mereka sudah mulai meninggalkan teknologi konvensional sementara yang dituntut dari pengguna lulusan adalah kemampuan teknis lulusan yang dapat mengombinasikan kedua teknologi guna mendukung pelaksanaan tugas dan pekerjaan.

Kemampuan teknis dalam artian dapat menggunakan gadget yang dimilikinya, sehingga dapat dikatakan bahwa para lulusan memang tidak gagap teknologi. Mereka telah cukup memiliki digital capability tetapi sesuai jenjang literasi digital. Para lulusan ini baru mencapai di level pertama yaitu kompetensi digital dimana konsep dan pendekatan sudah mengarahkan mereka pada sikap-sikap dan pemikiran akan kebutuhan kemampuan penguasaan teknologi digital, namun mereka harus terus didorong untuk tetap berproses menuju kompetensi literasi digital. Analisis pada pengguna menunjukkan bahwa para lulusan program studi Kearsipan belum memiliki soft skills seperti yang dibutuhkan oleh dunia kerja. Hal ini mengacu pada tingkat keberhasilan literasi digital yang belum mampu mereka tunjukan, baik di saat magang maupun ketika mulai bekerja. Jenis literasi digital yang dibutuhkan sesuai permintaan pengguna bisa mengacu pada tabel 2

\section{KESIMPULAN}

Penelitian ini sudah berhasil mengidentifikasi soft skills apa saja yang menjadi kebutuhan dunia kerja kearsipan. Di berbagi bidang pada lulusan lulusan program studi Kearsipan akan saling berkompetisi dan berkarir dengan memanfaatkan soft skills yang dimiliki. Disamping soft skills yang bersifat mendasar seperti kemampuan komunikasi, interaksi, koordinasi, kerja sama, serta kepemimpinan. Kebutuhan soft skills seorang lulusan program studi Kearsipan bertambah dengan perlunya kompetensi literasi digital. Kemampuan kompetensi literasi digital akan mendukung pelaksanaan tugas dan pekerjaan.

Upaya pencapaian keberhasilan literasi digital sudah harus dapat difasilitasi oleh kampus sejak dini. Upaya tersebut dapat dilaksanakan melalui pengembangan metode pembelajaran yang terus memperbaharui kebutuhan dunia kearsipan, memberikan kebebasan kepada mahasiswa untuk menjelajah dan memanfaatkan teknologi digital dalam rangka penyelesaian tugas kuliah maupun 
tugas akhir serta teknik pelaporan ilmiah. Guna membantu calon lulusan kearsipan dalam mencapai kompetensi soft skills, diperlukan pelatihan pengelolaan kearsipan secara modern. Lulusan kearsipan mampu mengakses data dan pengetahuan serta memformulasikan dan menyajikan kembali sebagai sebuah informasi penting kepada masyarakat. Kemampuan memanfaatkan teknologi digital untuk menyelesaikan berbagai tugas dan pekerjaan akan menjadi tolok ukur baru bagi kompetensi soft skills para lulusan program studi Kearsipan.

\section{SARAN DAN UCAPAN TERIMAKASIH}

Perlu dilakukan penelitian lebih lanjut untuk dapat mengetahui persentase capaian mahasiswa vokasi khususnya program Kearsipan sesuai pengelompokan kebutuhan literasi digital. Perlu penyesuaian kurikulum dan metode pembelajaran dalam upaya pemenuhan kebutuhan soft skills mahasiswa vokasi khususnya program Kearsipan. Terima kasih kepada para informan yang telah bersedia menyampaikan masukan dan pendapatnya serta kepada Universitas Terbuka yang telah memfasilitasi penelitian ini.

\section{DAFTAR PUSTAKA}

Asari, Andi dkk. 2019. Kompetensi Literasi Digital Bagi Guru Dan Pelajar Di Lingkungan Sekolah Kabupaten Malang. BIBLIOTIKA: Jurnal Kajian Perpustakaan dan Informasi Vol.3, No.2: 98 - 104

Bawden, D. 2001. Information and digital literacies: a review of concepts. Journal of documentation, Vol.57 No.2: 218-259

Boyd, D., dan Crawford, K. 2012. Critical Questions for Big Data. Information, Communication \& Society. Vol.15, No.5: 662-679

Buckingham, D. 2007. Digital Media Literacies: rethinking media education in the age of the Internet. Research in Comparative and International Education, Vol.2, No.1: 43-55

Eshet-Alkalai, Y. 2004. Digital Literacy: A Conceptual Framework for Survival Skills in the Digital Era. Journal of Education Multimedia and Hypermedia, Vo.13, No.1: 93-106.f

Jordana, T. A. dan Suwarto, D. H. 2017. Pemetaan Program Literasi Digital di Universitas Negeri Yogyakarta. Jurnal INFORMASI Kajian Ilmu Komunikasi Vol.47, No. 2: Desember 2017. 167-180

Kenton, J., Blummer, B. 2010. Promoting digital literacy skills: examples from the literature and implications for academic librarians. Community \& Junior College Libraries, Vol.16, No.2: 84-99

Lankshear, Colin., Knobel, Michele. 2008. Digital Literacies: Concepts, Policies, and Prectises. New York: Peter Lang Publishing, Inc.

Lazuardhi Utama, 2020. Ada 3 Jenis Kompetensi Yang Harus Dikuasai. https://www.viva.co.id/digital/ digilife/1287643-unicef-ada-3- Minggu, 26 Juli 2020 | 04:30 WIB. Diunduh tgl. 10 Agustus 2020

Peraturan Kepala Arsip Nasional Republik Indonesia Nomor 12 Tahun 2017 tentang Grand Design Pembinaan Sumber Daya Manusia Kearsipan diunduh melalui https://jdih.anri.go.id/peraturan/12_2017\%20Perka\%20Grand\%20Design\%20Pembinaan\%20SDM\%20Kearsipan\%20 FINAL\%20(1).pdf pada tanggal 29 Juli 2020

Riel, J., Christian, S., \& Hinson, B. 2012. Charting digital literacy: A framework for information technology and digital skills education in the community college. Presented at Innovations (March 2012) Philadelphia, PA: 1-22 